\title{
Recorreguts geològics i mineralògics per la comarca de l'Alt Palància: des de Viver a Teresa $i$ Begís
}

\author{
Josep Maria Mata-Perelló \\ Joaquim Sanz Balagué \\ Jaume Vilaltella Farràs
}

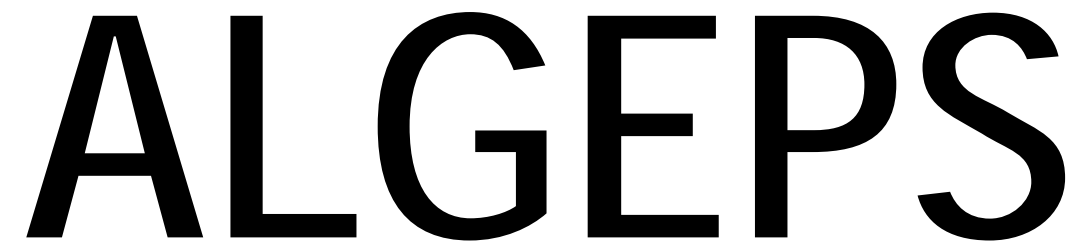

\section{REVISTA DE GEOLOGIA}

\section{n. 4}

DESEMBRE 2014 


\title{
RECORREGUTS GEOLÒGICS I MINERALÒGICS PER LA COMARCA DE L'ALT PALÀNCIA: DES DE VIVER A TERESA I A BEGÍS
}

\author{
Josep Maria Mata-Perelló \\ Museu de geologia Valentí Masachs, Escola Politècnica Superior d'Enginyeria de Manresa \\ (EPSEM), Universitat Politècnica de Catalunya · BarcelonaTech (UPC), 08272 Manresa, Spain
}

\section{Joaquim Sanz Balagué}

Departament d'Enginyeria Minera i Recursos Naturals (EMRN), Escola Politècnica Superior d'Enginyeria de Manresa (EPSEM), Universitat Politècnica de Catalunya - BarcelonaTech (UPC), 08272 Manresa, Spain

\section{Jaume Vilaltella Farràs}

\section{Paraules clau: Patrimoni geològic i miner; Sistema ibèric; País Valencià}

\section{Resum}

Itinerari realitzat el dia 7 de desembre del 2013. Aquest itinerari geològic i mineralògic, discorrerà íntegrament dintre del Sistema Ibèric, tot $i$ que molt lluny de la denominada Zona d'Enllaç. Malgrat aquesta circumstància, aquesta zona es troba afectada per fractures de direcció catalana, de rumb NE - SW (i NNE - SSW), fonamentalment.

Així, en aquesta ocasió la totalitat del recorregut es situarà en part dintre dels denominats relleus triàsics de Sagunt (definits per Oriol RIBA et altri, 1976). D'aquesta manera, en la major part dels trajectes anirem trobant afloraments dels diferents materials mesozoics. Aquests en un principi són triàsics, passant després a també trobar-se afloraments dels materials del Juràssic i del Cretàcics, segons els indrets per on discorri l'itinerari.

Per d'altra banda, cal dir que aquest itinerari transitarà per una sola comarca: concretament per la del Alt Palància. Així, s'iniciarà per les immediacions de la població de Viver per a cloure prop de la població de Begís, quasi al límit septentrional de la comarca, molt prop de la comarca aragonesa de Gúdar - Javalambre (de les terres de Teruel)

Per d'altra banda, cal dir que aquesta comarca és una de les que composen la Regió de Segorbe / Sogorb.

\section{Objectius fonamentals}

Els objectius fonamentals que es pretenen aconseguir en la realització d'aquest itinerari, es poden concretar en els següents aspectes generals, d'acord amb el sentit de la marxa:

1.- Estudi i observació dels materials mesozoics, que constitueixen el Sistema lbèric, per on discorrerà la totalitat del recorregut de l'itinerari, entre les poblacions de Viver i Begís. Aquests 
materials pertanyeran en bona part al Mesozoic (repartint-se entre el Juràssic, el Cretàcic i el Triàsic).

2.- Observació de les estructures del Sistema Ibèric, dintre dels trams dels recorregut. Aquestes estructures es troben constituïdes en la seva major part per fractures de diverses direccions, fonamentalment de les estructures "ibèriques" i de les estructures "catalanes". En el primer cas de direcció aproximada: WNW - ESE i en el segon NE - SW, gairebé perpendiculars.

3.- Observació dels diferents indrets relacionats amb el nostre Patrimoni Geològic que anem trobant al llarg del recorregut de l'itinerari, i en especial dels que puguin ésser catalogats com a LIG (Llocs d'interès Geològic).

4.- Observació dels diferents indrets relacionats amb el nostre Patrimoni Miner que anem trobant al llarg del recorregut de l'itinerari, i en especial dels que puguin ésser catalogats a LIPM (Llocs d’Interès del Patrimoni Miner).

\section{Antecedents}

No tenim coneixement de cap antecedent bibliogràfic relatiu al recorregut del present itinerari, ni nostre ni de cap altre autor. Tot i així hi ha dos antecedents nostres: MATA -.PERELLÓ i VILALTELLA FARRÀS (2005 i 2011), en un recorregut força semblant al que ara presentem. Tanmateix, farem referencia a un recorregut molt recent nostre; es tracta de MATA - PERELLÓ i VILALTELLA FARRÀS (2013).

En relació a les característiques geològiques farem esment de dos treballs generals, relatius al conjunt dels Països Catalans: GUIMERÀ et altri (1992), i RIBA et altri (1976). Igualment, cal fer esment dels diferents fulls del Mapa Geológico de España corresponents a la zona per la qual discorrerà el recorregut de l'itinerari.

En relació al Patrimoni Miner, farem esment d'un treball molt recent nostre: MATA - PERELLÓ et altri (2012).

Tots aquests treballs esmentats, i d'altres, figuraran per ordre alfabètic a l'apartat dedicat a la bibliografia.

\section{Recorregut de l'itinerari}

El recorregut de l'itinerari s'iniciarà a la població de Viver, per on s'efectuaran diverses aturades, entre la població i el riu Palància. Posteriorment, es sortirà cap al ponent, per tal d'anar cap a la propera població de Teresa, per las carreteres CV - 2352, CV - 236 y finalment por la CV - 235 En aquest recorregut es faran les primeres aturades: una d'elles en sortir de la població de Viver, i les altres dos poc abans d'arribar a Teresa.

Després el recorregut es dirigirà cap a Begís, seguint inicialment la carretera CV - 235; però abans d'arribar a la Venta de Begís, es faran dues aturades més, totes dues a la vora de la carretera i del riu Palància. Després, en arribar al poble de Begís, es realitzarà la darrera aturada, finalitzant el recorregut de l'itinerari. 


\section{Advertiments previs}

Com en altres recorreguts de recerca geològica i mineralògica ..., si es disposa del temps suficient, poden efectuar-se passant per totes les parades i filloles. En cas contrari, recomanem prescindir de les anomenades parades - condicionals.

També cal tenir en conte que una part del recorregut final de l'itinerari, es realitzarà per camins de terra, per la qual cosa caldrà prendre les degudes precaucions. Així, d'aquesta manera es circularà pels diferents camins d'accés a algun dels punts d'observació.

Cal tenir, com sempre, una cura molt especial de respecte a la natura, al llarg de tot el recorregut de l'itinerari, i també fora d'ell.

\section{Descripció de l'ítinerari}

Com en altres itineraris, a continuació veurem una sèrie de "parades o estacions". En cada una d'elles es farà un breu comentari, ja sigui de caràcter geològic, geomorfològic o mineralògic, segons s'escaigui.

Per d'altra banda, darrera del nom de l'indret (o de la parada), situarem entre parèntesi el número del Mapa Topogràfic, a escala 1:50.000, on es troba l'indret de l'aturada. En aquesta ocasió, utilitzarem solament un full de l'esmentat mapa topogràfic; concretament, el 639 (Jerica). Al respecte, cal dir que aquests fulls han estat publicats pel Instituto Geográfico y Catastral de España.

Així doncs, la relació general de les aturades que constitueixen aquest itinerari, d'acord amb el sentit de la marxa, és el següent:

\subsection{Parada 1. Las Cuevas del Salgar, (terme municipal de Viver, comarca de l'Alt Palància). (Full 639).}

Tot i que el recorregut de l'itinerari haurà començat al poble de Viver, caldrà sortir per la carretera que es dirigeix cap a ponent, cap a Teresa, Toràs i Begís; això és, la carretera CV 2352. Al poc de sortir, es trobarà una carretereta per l'esquerra, la qual condueix (entre altres llocs) cap el paratge de las Cuevas del Salgar. Ens caldrà agafar aquesta ruta i en arribar al paratge en qüestió, farem la primera aturada. Així, haurem recorregut uns $3{ }^{\prime} 5 \mathrm{Km}$ des de Viver.

En aquest recorregut, hem anat trobant afloraments dels materials mesozoics de la Fàcies Pueberk, que en la seva major part pertanyen al Juràssic en trànsit al Cretàcic. Es tracta d'alternances de gresos, calcolutites i de nivells carbonatats. Aquests materials es situen dintre del Sistema Ibèric, per on efectuarem tot el recorregut del present itinerari.

Aquest materials són també els que hi ha al substrat de l'indret on farem la present aturada. Tot $\mathrm{i}$ això, aquí es troben recoberts per terrenys més recents, de caràcter eminentment travertínic, del Neogen, concretament del Pleistocè.

Així, en aquest indret, podem fer una bona observació dels materials travertínics, entre els quals s'han originat nombroses coves, surgències i fins i tot aprofitaments de l'aigua. (fotografies 1 i 2 ). 


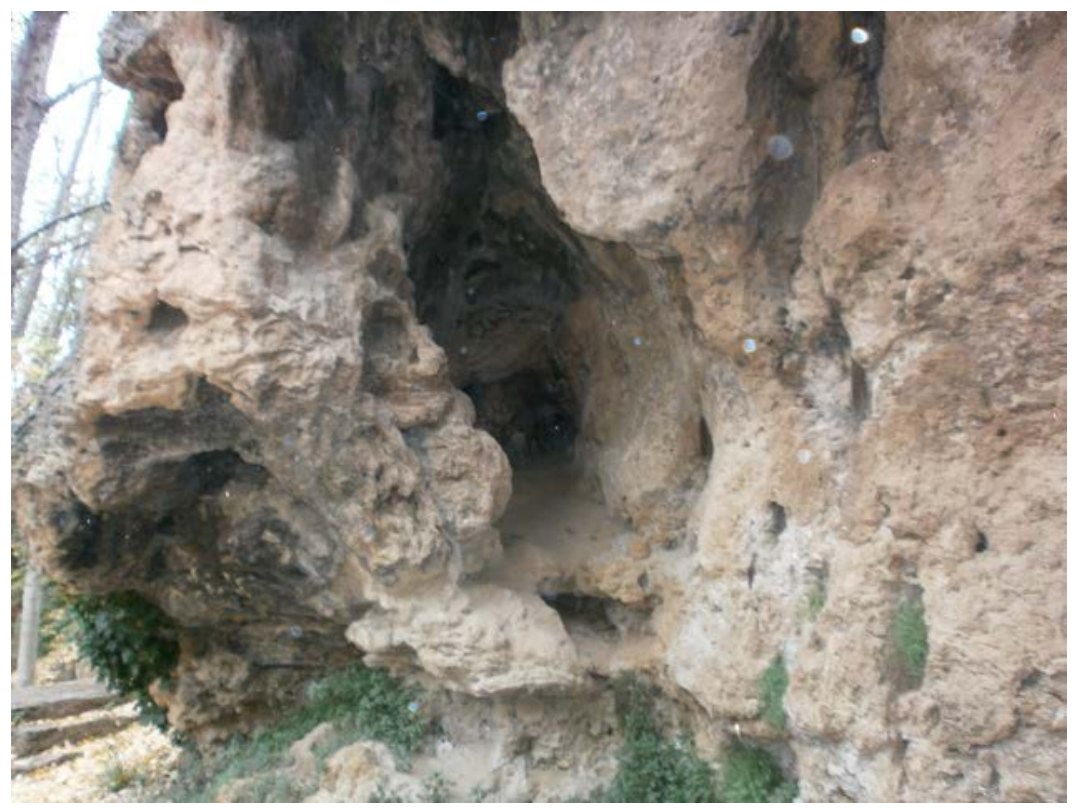

FOTOGRAFIA 1. Un aspecte dels travertins del paratge del Salgar (Vives, Alt Palància). Novembre, 2013

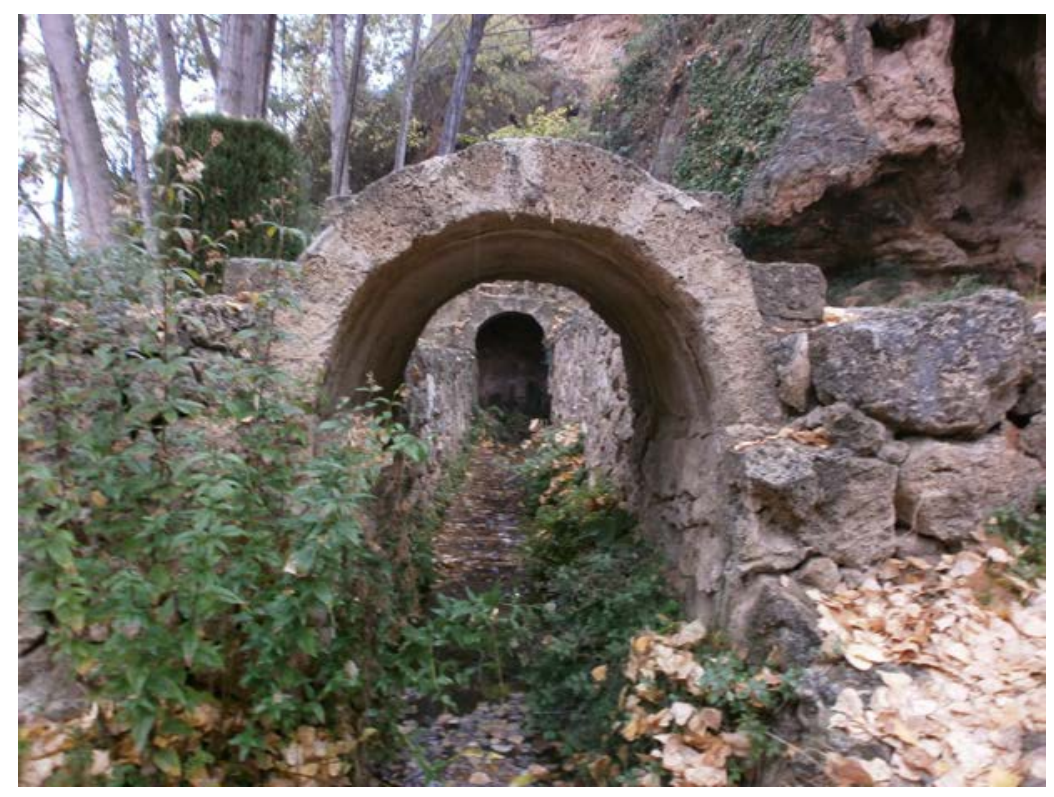

FOTOGRAFIA 2. Aprofitament de l'aigua de les surgències al Salgar i de la utilització dels travertins . Novembre, 2013

Finalment, també cal dir que en aquest indret hi ha un antic poblat del Neolític, que correspon a un assentament d'aquella època. A l'actualitat es troba molt malmès. Tanmateix hi ha diverses coves, degudament senyalitzades. 


\subsection{Parada 2 - Condicional. La Fábrica de Luz, (Terme Municipal de Viver, Comarca de I’Alt Palància). (Full 639).}

Molt prop de l'indret de l'aturada anterior, hi ha les restes d'una antiga fàbrica de llum. En aquest indret, farem una nova aturada, a menys de $1 \mathrm{Km}$ de l'anterior. A més a més, per aquest Iloc ja hi hem passat a I'anada cap el Salgar.

En aquest recorregut, hem trobat els materials esmentats a l'aturada anterior. Tanmateix, són els que afloren a l'indret de la present aturada.

Aquí hi ha les restes d'una antiga fàbrica de llum. Aprofitava l'aigua d'un canalet procedent d'un azud situat sobre el riu Palància. A l'actualitat es troba pràcticament esfondrada.

\subsection{Parada 3. Cascada de las Peñas Rubias, (Terme Municipal De Viver, Comarca de I’Alt Palància). (Full 639).}

Després de realitzar la parada anterior, cal recórrer uns 0’3 Km per la carretereta que enllaça Viver amb les Coves del Salgar. Així, en aquest lloc farem una nova aturada.

En aquest breu recorregut, hem anat trobant els materials mesozoics que hem esmentat anteriorment. I també hem trobat afloraments dels travertins del Pleistocè, que hem vist a la primera aturada.

Des d'aquest indret, mirant cap a l'altra banda del riu Palància, es fa força palesa una cascada que baixa cap el riu, pel Barranc de la Chana. (fotografia 3).

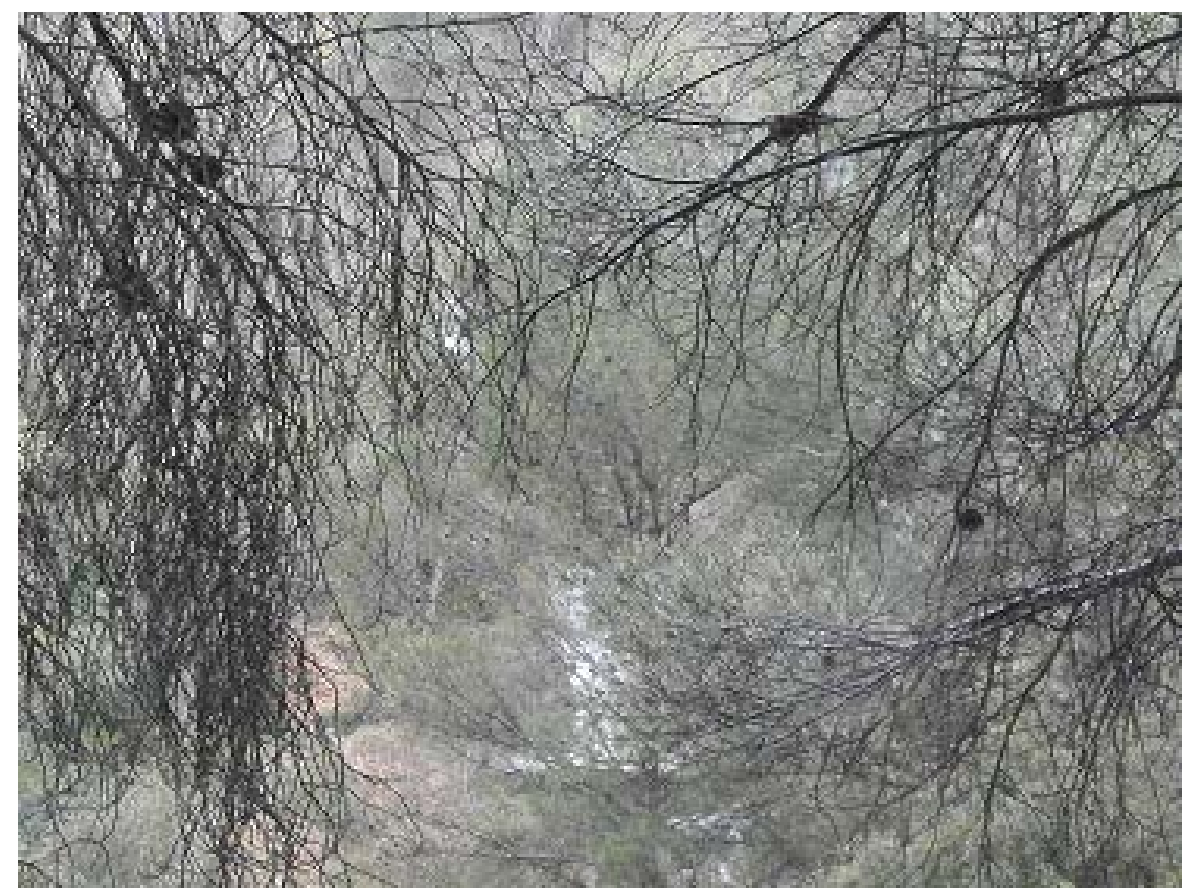

Fotografia 3 Cascada de las Peñas Rubias, des de la carretera de Viver a les Cuevas del Salgar, prop de la fàbrica de la Llum. Novembre, 2013 


\subsection{Parada 4 - condicional. Carretera a Teresa, CV-235, immediacions del km 4 , (terme municipal de Viver, comarca de l’Alt Palància). (Full 639).}

Després de realitzar-se la parada anterior, cal retornar cap a la carretera que se'n va cap a Teresa, la CV - 2352. Poc després enllaçarem amb la carretera CV - 235, per la qual ens anirem apropant cap a Teresa. Així, després de deixar el trencall de Torás, en arribar al Km 4, caldrà fer una nova aturada, a uns $4^{\prime} 5 \mathrm{Km}$ i escaig de l'anterior, aproximadament.

En aquest recorregut, inicialment hem anat trobant afloraments dels materials esmentats a la parada anterior. Aquests es troben constituiits per nivells de gresos, argiles i calcàries i són els que apareixen a l'indret de la present aturada.

En aquest lloc ens trobem en una interessant discordança entre els materials acabats d'esmentar i els del Neogen que els cobreixen, del Pliocè i del Pleistocè, fonamentalment, de caràcter eminentment detrític

\subsection{Parada 5. Carretera a Teresa, CV-235, immediacions del km 4’2, (terme municipal de Viver, comarca de I’Alt Palància). (Full 639).}

Després de realitzar-se la parada anterior, cal seguir per la carretera que se'n va cap a Teresa (la CV - 235), per tal de fer un curt recorregut de menys de $0^{\prime} 2 \mathrm{Km}$, des de la parada anterior. Com al cas anterior, farem l'aturada a la vora de la carretera.

En aquest breu recorregut, hem anat trobant els materials esmentats a la parada anterior, els quals pertanyen al Juràssic. Aquests materials es troben constituïts per trams de calcàries, gresos i calcàries. Aquests materials, de tonalitats lleugerament rogenques - granatoses, pertanyen a la Fàcies Purberk, de transició del Juràssic al Cretàcic, tot i que aquí són fonamentalment del primer període esmentat.

En aquest indret es fa palesa una fractura que talla als materials anteriors, els quals es troben recoberts pels terrenys detrítics quaternaris i pliocènics, discordants amb els del mesozoic. (fotografia 4).

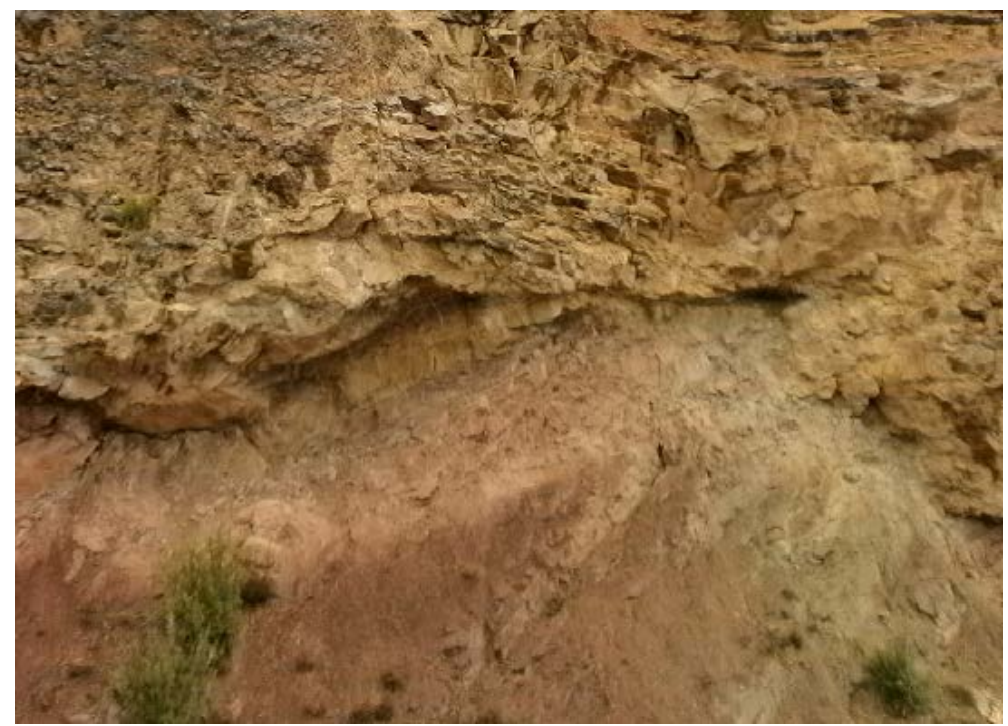

Fotografia 4. Un aspecte de la discordança entre els materials mesozoics i els neògens. Novembre, 2013 
Per d'altra banda, en aquest indret es veu també una estructura d'escurçament entre els materials anteriorment esmentats del mesozoic de la Fàcies Purberk.. Tot això és el que es veu a la fotografia 5.

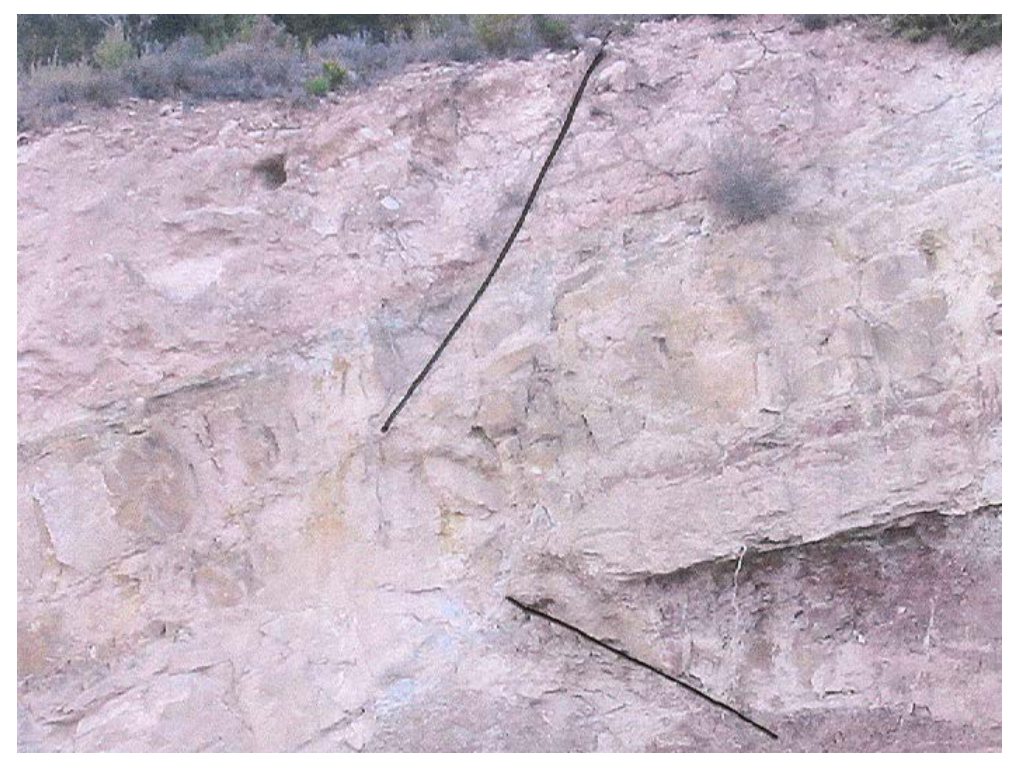

Fotografia 5. Un aspecte de les fractures visibles en aquesta aturada. Juny 2006

\subsection{Parada 6. Carretera a Begis, CV-235, immediacions del km 9’8, ( terme municipal de Teresa, comarca de I’Alt Palància). (Full 639).}

Després de realitzar-se la parada anterior, cal retornar a la carretera CV - 235, per tal de continuar cap a Teresa. En arribar al poble, cal travessar-lo per tal de seguir cap a Begís. En arribar a les immediacions del $\mathrm{Km} 9$ 9'8 cal fer una nova aturada, a quasi $6 \mathrm{Km}$ de l'anterior.

En aquest recorregut, hem travessat els materials carbonatats juràssics. En arribar a les immediacions del km 9, haurem començat a trobar unes fractures clarament catalanes, de direccions generalitzades NE-SW i NNE - SSW. Aquestes fractures tallen als materials carbonatats anteriors.

En aquest lloc es pot fer una observació de les calcàries mesozoiques del Triàsic (concretament del Muschelkalk). Aquestes calcàries es troben intensament fracturades, com a conseqüència de les falles acabades d'esmentar. Per d'altra banda, aquestes calcàries triàsiques, es fan especialment paleses a l'altra banda del riu Palància. (fotografia 6).

\subsection{Parada 7. Carretera a Begis, prop del Km 10`2, ( terme municipal de Teresa, comarca de I’Alt Palància). (Full 639).}

Després de realitzar-se la parada anterior, cal seguir per la carretera, anant cap a Begís (que continua essent la CV - 235). Just quasi en arribar a la Venta de Begís, caldrà fer una nova aturada, a menys de 0 ' $5 \mathrm{Km}$ de la parada anterior. 


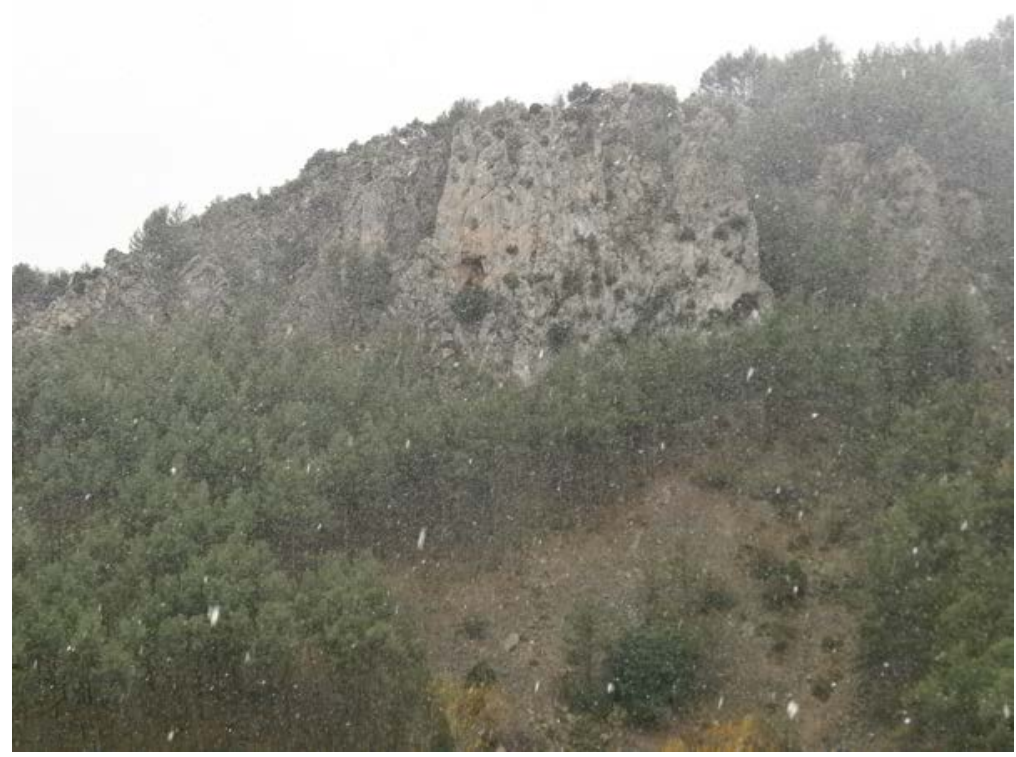

Fotografia 6. Les calcàries del Muschelkalk bora el riu Palància a Teresa. Novembre 2013, durant una nevada

En aquest recorregut. Hem anat travessant els materials triàsics. Inicialment hem trobat els carbonatats del Muschelkalk. Tot i això, immediatament hem trobat afloraments del Keuper. Però ben de seguida hem tornat a trobar afloraments dels trams carbonatats. Aquests són els que hi ha a l'indret de l'aturada.

En aquest lloc, aquests materials carbonatats formen el flanc d'un plec. Concretament, es tracta d'un anticlinal, el qual es troba esventrat pel riu Palància. El plec te una clara direcció ibèrica. El riu descriu un petit congost, en travessar aquests materials carbonatats. (fotografia 8).

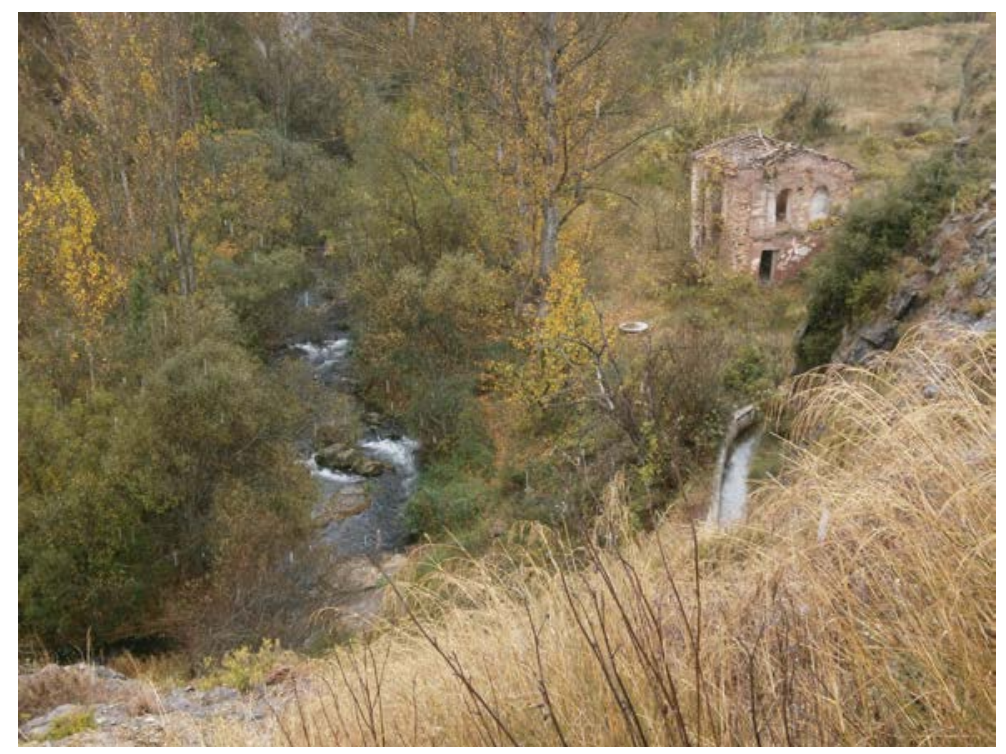

FOTOGRAFIA 7. El riu Palància en travessar les calcàries del Muschelkalk, Novembre 2013 
Per sobre d'aquests materials afloren els trams argilosos i guixosos del Triàsic Superior, del Keuper.

\subsection{Parada 8. Carretera de Begís a Arteas, $\mathrm{Km} \mathrm{1’2,} \mathrm{(} \mathrm{terme} \mathrm{municipal} \mathrm{de} \mathrm{Begís,}$ comarca de l’Alt Palància). (Full 639).}

Després de realitzar-se la parada anterior, cal seguir per la carretera, anant cap a Begís. Més endavant, en arribar al poble, caldrà sobrepassar-lo, per tal d'agafar la carretereta que es dirigeix cap el poblet d'Arteas. Quasi a la sortida de Begís, farem la present aturada, la darrera d’aquest itinerari. Així, haurem recorregut uns 4 Km més.

En aquest recorregut, hem anat trobant els materials mesozoics que ja hem vist a les aturades anteriors. Així, haurem vist afloraments dels materials carbonatats del Juràssic i també del Triàsic (concretament del Muschelkalk). Tanmateix, haurem vist afloraments dels nivells de guixos del Triàsic Superior, del Keuper.

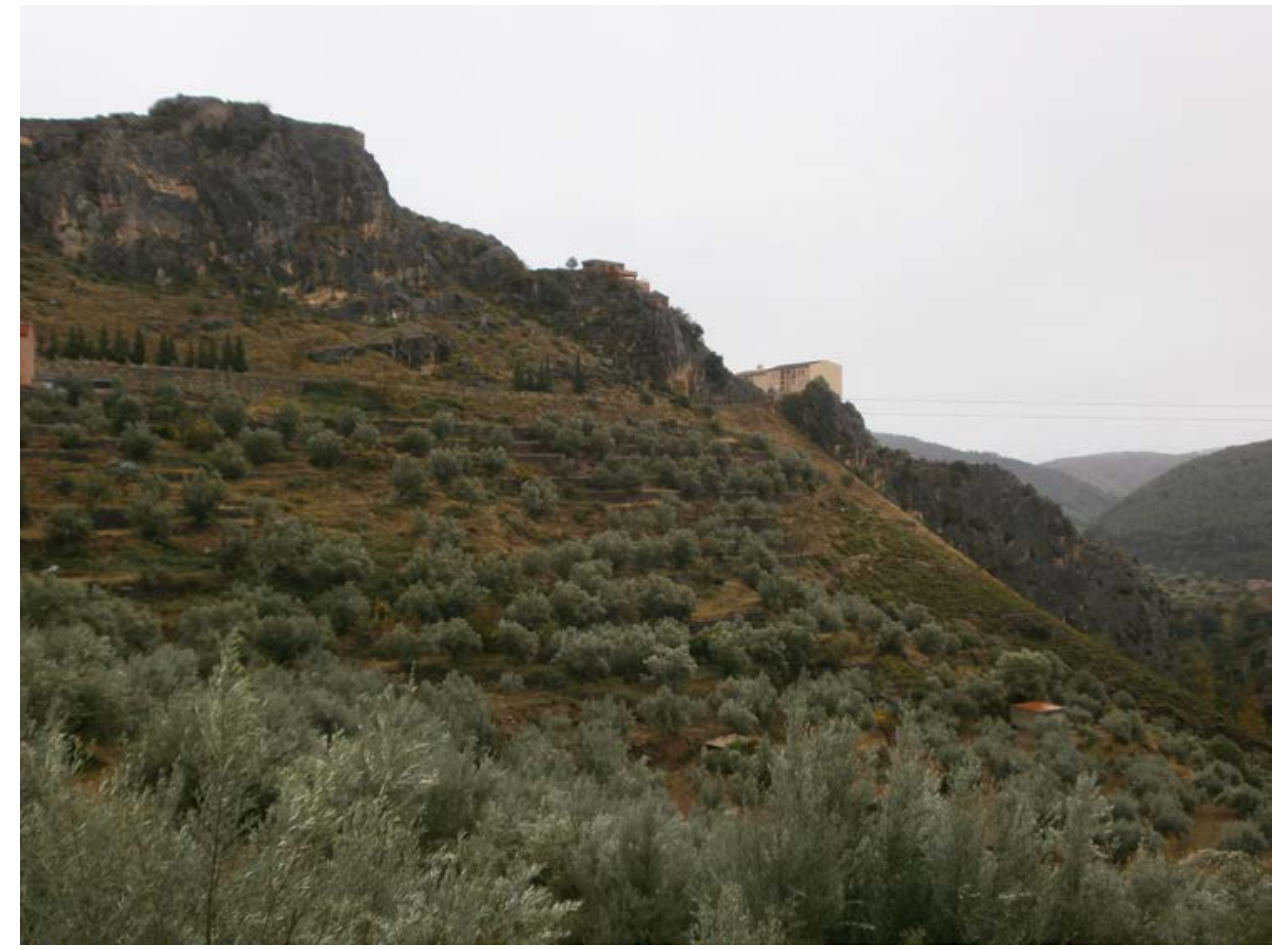

Fotografia 8. La població de Begís (sobre calcàries del trànsit del Juràssic al Cretàcic) al costat del riu Arteas.

El congostet del riu Arteas (sobre calcàries Triàsiques del Muschelkalk), per sobre del barri de Rios de Abajo (Begís). Novembre 2013

Des d'aquest indret, es pot veure una bona perspectiva del riu d'Arteas (afluent del riu Palància, procedent dels poblets d'Arteas de Arriba i d'Arteas de Abajo) el qual envolta la població de Begís. També es pot veure un congostet que forma en travessar les calcàries del Muschelkalk, aigües avall de Begís, prop del barri de Rios de Abajo. (fotografies 8 i 9 ). 


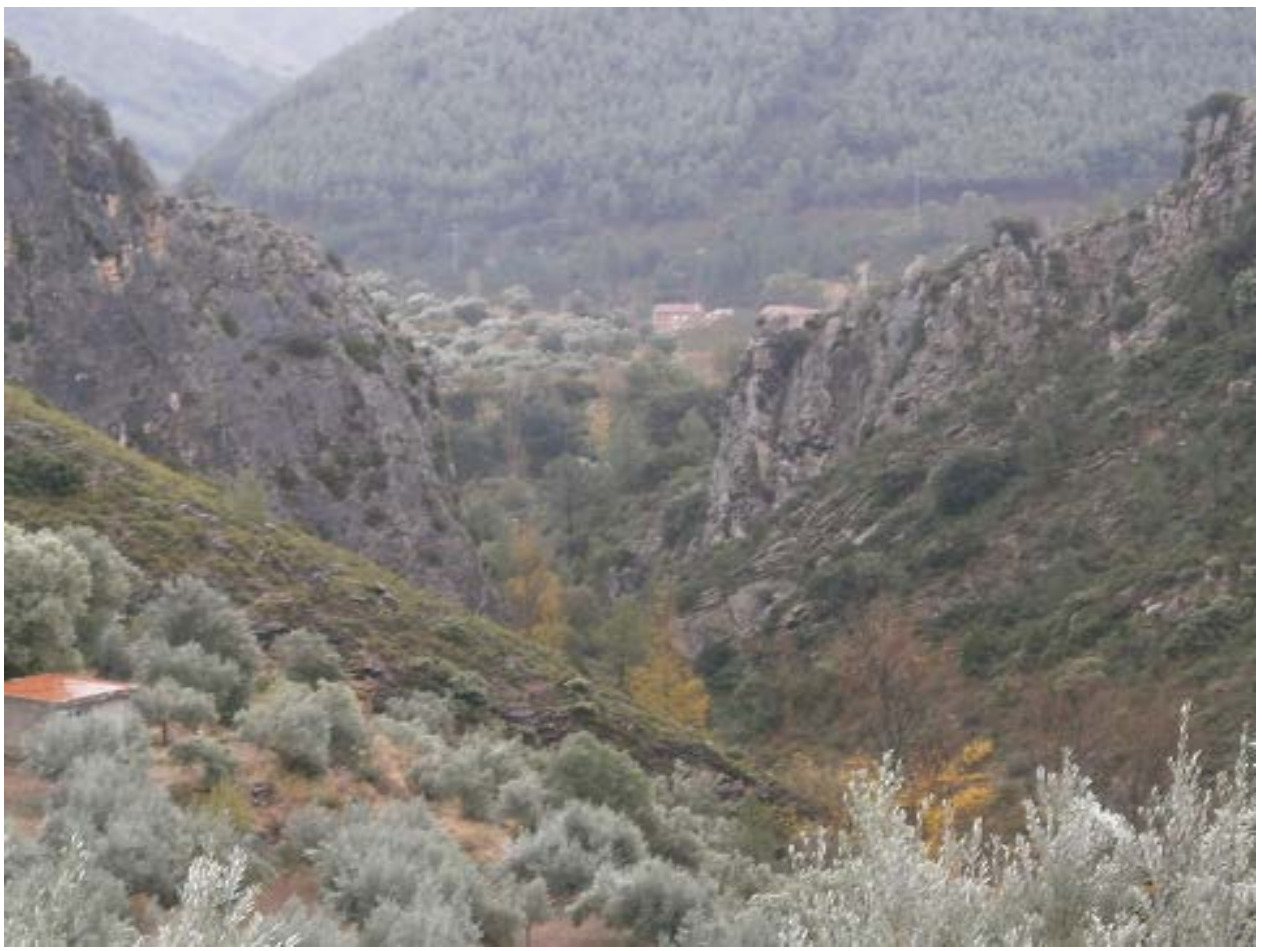

Fotografia 9. El congostet del riu Arteas (sobre calcàries Triàsiques del Muschelkalk), per sobre del barri de Rios de Abajo (Begís).

En aquest indret finalizta aquest recorregut

\section{Bibliografia}

GUIMERÀ, J. et altri /1992).- Geologia (II), Història Natural dels Països Catalans, Vol.2, 547 pag. Enciclopèdia Catalana, S,A,, Barcelona

IGME (1974).- Mapa Geológico de España, a escala 1:50.000, 2a Sèrie. Hoja i memòria no 614 (Manzanera). Inst. Geol. Minero de España. Minist. Indústria. Madrid.

IGME (1974).- Mapa Geológico de España, a escala 1:50.000, 2a Sèrie. Hoja i memòria $n^{\circ} 639$ (Jerica). Inst. Geol. Minero de España. Minist. Indústria. Madrid

LÓPEZ, J. i ARCHE, A. (1986).- Estratigrafia del Pérmico y Triásico, en facies Buntsandsteim y Muschelkalk, en el sector Sudeste de la rama castellana de la Cordillera Ibérica (Provincias de Cuenca y de Valéncia). Estudios Geológicos, nº. 42, pp. 123-143. Madrid

MATA-PERELLÓ, J.M. (1984).- Els Minerals del País Valencià, Col-lecció Informe, nº 6, 546 pàgines. Manresa 
MATA-PERELLÓ, J.M. i SANZ BALAGUER, J. (1988).- Guia de determinació de Minerals, adaptada als Països Catalans. Parcir, Edicions Selectes, 207 pàgines. Manresa.

MATA-PERELLÓ, J.M. i VILALTELLA FARRÀS, J. (2005).- Recorreguts geològics i mineralògics per la comarca de l'Alt Palància: des de Viver a Teresa, Begís i a Torás. Inèdit. 8 pag. Manresa

MATA-PERELLÓ, J.M. i VILALTELLA FARRÀS, J. (2011).- Recorreguts geològics i mineralògics per la comarca de l'Alt Palància: des de Viver a Teresa, Begís, Torás, Toro i a Barracas. Inèdit. 10 pàgines. Manresa

MATA-PERELLÓ, J.M. i VILALTELLA FARRÀS, J. (2013).- Recorreguts geològics i mineralògics per la comarca de l'Alt Palància: des de Viver a Teresa, Begís, Torás, al Toro i a Barracas. Inèdit. 12 pàgines. Manresa

MATA-PERELLÓ, J.M. et altri (2012).- El patrimonio minero de la comarca del Alto Palància (Castellón, Comunidad Valenciana, Sistema Ibérico). Actas del XIII Congreso internacional sobre patrimonio geològico y minero, pp. 743 - 752. Manresa

RIBA, O. et altri (1976).- Geografia Física dels Països Catalans. Edit. Ketres, 254 pàgines. Barcelona. 